\title{
Pop Music
}

\author{
By INGVILD TOMREN
}

On February 1, pop star legend Amr Diab ('Amr Diyāb) releases the music video of his latest song on his YouTube channel. Al-Qāhira ("Cairo"), a collaboration between himself and another beloved Egyptian artist, Mohamed Mounir (Muhammad Munīr), is to no one's surprise an instant hit. The video's opening scene shows Diab standing on the rooftop of the

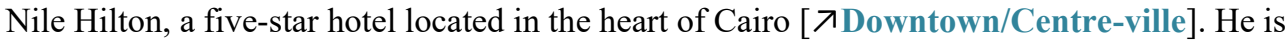
gazing over the Nile, soaking in the city view as the sun is about to set, seemingly in awe of its beauty. Then he turns towards the camera and the song starts:

It is like a beautiful girl calling for you. It has a secret that makes it always beautiful in your eyes. How magical she is! I adore her. I love her. (YT "Al-Qāhira”)

The band accompanying him includes many traditional Arabic instruments as well as an electric guitar, mixing traditional music with western sound elements, a proven Diab-recipe for a successful pop song. In the middle of the video a smiling Mounir enters as he joins in on the chorus. The pair of them look as if they are sitting at a café discussing a beautiful girl, a scenery that matches the lyrics perfectly as they go on singing about Cairo's secret stories, her beauty and long nights (YT "Al-Qāhira").

The song is essentially a love declaration to Egypt's capital and generates lots of enthusiastic greetings in the commentary field, from all over the Middle East. However, there is a split in public opinion as many seem to disagree with this romanticized depiction of Cairo, especially during these challenging times [ $\nearrow$ Beautiful vs. Ugly]. In her article "This is NOT Egypt," published two weeks after the video is released, Sonia Farid writes:

While the song scored thousands of views immediately after its release and was the most shared and trending on the day it was posted online, it did not receive a warm welcome from a sizeable segment of Egyptians, who wondered whose Cairo the song featured. (FARID)

Farid compares the critical reactions to Al-Qähira to the negative response of the "This is Egypt" campaign, launched by the Egyptian Tourism Authority three months earlier (YT “This Is Egypt") [ЛThe Voice from Above]. Both videos present a picture-perfect Egypt: carefree people enjoying themselves on sandy beaches under blue skies, or on top of fancy buildings in a perfect sunset, with no pollution, poverty or garbage in sight [ $\lambda$ Garbage] Some describe the Al-Qāhira video as "classist", asking why they didn't shoot it by the Nile in a more working-class neighbourhood, rather than from above in one of Cairo's most luxurious hotels. Journalist Liza Dunham comments on the \#This is Egypt video, wondering how many hours it took the producers to Photoshop the pollution out of the colours. Yet others strike back against the critics asking them if they would rather prefer to show only the negative aspects of Egypt, such as the slums and garbage (FARID) [ $\nearrow$ Beautiful vs. Ugly, $\lambda$ Affluence vs. Destitution].

Journal of Arabic and Islamic Studies $\bullet 21(2021)$ - Themed Section In2016: *206-*213 (C) Ingvild Tomren, Dept. of Culture Studies and Oriental Languages (IKOS), Univ. of Oslo, NO 
Either way, there is probably no one better to promote a glossy image of Cairo than Amr Diab, still going strong in 2016 as the biggest Egyptian pop idol for more than three decades. Well into his fifties now, judging by his recent album covers, he arguably looks closer to thirty. His musical career continues to bring highlights and later this year he finally receives a Guinness World Record for winning the most World Music Awards for 'Best Selling Middle Eastern Artist' (cairoSCENE [a]). (Some also claim he should win an additional award for "the least aging man.") His response on Twitter is: "I am very proud to be the first Arab singer to achieve a \#guinessworldrecord title. Thank you@GWR"(@amrdiab).

On the flip side, the industry is also taking its toll on some of the most prominent artists. In the end of February, number one female voice in Egypt, Sherine Abdel Wahab (Shīrīn 'Abd al-Wahhāb), announces her retirement after sixteen years in the limelight (HotArabic Music). The news causes a fuss in the Arab music and entertainment scene, and her huge fan base as well as music industry colleagues are in shock. Lebanese singer Elissa immediately responds to the news on twitter calling for Sherine to reverse her decision:

In case what we heard is true we can't accept this decision@sherineawahab U are an addition to the industry and we need you in these times. (HotArabicMusic) [ $\nearrow$ Social Media]

In addition to her music, Sherine has had a successful year filled with career highs in many arenas. This includes starring in her own Ramadan TV show Tarīqi (My Road) last summer, joining the judge's panel in season 3 of the Arabic The Voice and finally becoming the mentor for the winning contestant, Jordanian Nedaa Shrara (Nidā' Sharāra) — all of which makes the announcement even more upsetting. Speculations run high in the press and many possible reasons are discussed, from a personal crisis due to her recent divorce, to issues regarding her political comments and the critique she has been facing for voicing them (HotArabicMusic). After a couple of months Sherine comments on her own decision, speaking at the Mawazine Festival in Morocco [ $\nearrow$ Celebrities]. She explains openly how exhaustion and depression got the best of her:

"It got to such an extent that I thought about committing suicide-I actually thought about that more than once," says Abdel Wahhab, “(...) The stress of the work got to me. I had some panic attacks. Then that led to some deep depression. I was sad, I was concerned for my children, I was concerned for myself-it was a such a difficult time that I still find it hard to explain..." (SAEED) [ $\nearrow$ Psychiatrists, $\nearrow$ Suicide]

Luckily for her fans, Sherine soon recovers. In addition to the Mawazine Festival, she performs this summer at the Baalbek International Festival in Lebanon. By August she climbs to the top of the charts yet again with her newest release, Kull mughannī (Every singer), a duet with Hossam Habib (Husām Habīb, Vimeo "Kull mughannī”). The song becomes a huge hit, and a sign that the diva is fully back in business.

Aside from long time industry troupers like Diab, Mounir and Sherine, Egypt these days is also blooming with new, young alternative voices [ $\nearrow$ Young vs. Settled]. In contrast to more typical pop songs, mostly restricted to romance and clichés, the younger generation seems to represent a broader definition of what is considered popular music. As a result, what used to be strictly underground genres are becoming increasingly more mainstream, and in

jais • 21 (2021) - Themed Section In2016: *206-*213 
some cases even producing new pop stars. A good example of this phenomenon is the relatively newborn genre mahragānāt. Emanating from the ghettos of Egypt's biggest cities [ $\left.\nearrow^{\prime} A s h w \bar{a}{ }^{\prime} i y y \bar{a} t\right]$, mahragānāt has since the days of the Revolution been rapidly spreading all across Egypt, and further throughout the Arab World. The genre is rooted in traditional $s h a^{\prime} b \bar{\imath}$ music, mixed with foreign elements such as rap, hip hop and electronica. Its popularity has been growing ever since its emergence and the genre is now connected to a steady audience. There are multiple YouTube channels, videos and hundreds of songs to be found online. By now it has also become an obvious part of the city soundscape, and walking in the streets of Cairo these days you are very likely, if not guaranteed, to hear mahragānāt being played around you somewhere. It seems to be hard to avoid:

Whether you take a microbus, youngsters pass you by on a Vespa, or you go for a fun evening Nile trip on a boat, Mahraganat is everywhere. The music style has earned a spot during Saturday afternoons on Nile FM, there is an exclusive, privately owned Mahraganat channel on TV, and it has been embraced by alternative organizations such as Al Mawred Al Thaqafy, 100Copies, and the Downtown Contemporary Arts Festival (D-CAF). (Freemuse)

The latest mahragānāt hit sweeping the nation is Mafish șạhib yitșāhib (No friend acts as a friend) by group Shobek Lobek (Shubīk Lubīk). Six months after it was first published, the music video clip has already reached more than 30 million hits on YouTube. In March, the number increases to 50 million ( $a l-Y a w m$ al-Sābi). The song is also popular outside Egypt and comments on the video include greetings from people all across the Arab world:

This song is so nice!! (...) Love to our Egyptian brothers, from Algeria. - Love to darling Egypt from Iraq. - Egyptians are great people (...) Long live Egypt. Greetings from Saudi Arabia (YT "Mafīsh șāḥib yitșāḥib”) -

to quote only a few examples. In contrast to its wide popularity the song is also facing a lot of critique, especially concerning its lyrical content. A good example is an episode from the talk show 'Ākhir an-Nahār published on the show's YouTube page on February 10 (YT "Ākhir al-Nahār"). The young members of Shobek Lobek have been invited to talk about their hit. With them in the studio is the renowned Egyptian artist Helmy Bakr (Hilmī Bakr) who is criticizing the group claiming that their music has no meaning or purpose [ $\nearrow$ Young vs. Settled]. The artists' response to the criticism is simply that their song talks about what's going on in the streets and that people are affected by their lyrics. In another interview, singer Nasser Gandhi explains:

Our lyrics are the words we hear on the street. When someone attacks you, you can't be patient and call the police. You must defend yourself to survive. That's the reality that we're facing now and we have to deal with it. (GAMAL)

The biggest arena for mahragānāt music is the wedding party scene, and mahragānāt performances are now the norm in any Egyptian wedding. If you attend a street wedding these days, it is very likely that you'll find a mahragānāt artist performing in front of an enthusiastic crowd. It has become a flourishing industry, employing many young Egyptians, with thousands more trying to find their way into the scene (Freemuse). This popularity is

jais • 21 (2021) - Themed Section In2016: *206-*213 
also mirrored in the movie Ishtibāk ("Clash") where a group of people, representing different parts of Egyptian society, are trapped in a police van, with tension running high. Among them is a shäbb who calls himself "DJ Mans." He uses the opportunity while the group is circulating in front of the van's backdoor, gasping for fresh air, to pass out his card and promote his DJ business [ $\nearrow$ Clash] —an allusion to the fact that the mahragānāt genre is in the process of professionalizing and some actors in the scene have a strong wish to make it in the business.

Dancing is also a vital element of mahragānāt music and the genre has created a particular dancing style, mixing traditional moves with influence from western styles such as trance dance [ 7 Dancing]. The result is a series of intense and fast beat, freestyle moves. On YouTube there are various videos showing people from all ages dancing to mahragānātfrom youth at a local wedding to old men dancing in the street (YT "Egyptian dancing on the popular song 2016"). The dance factor is huge and has even brought the music to the Egyptian elite. Occasionally, and mainly at wedding celebrations, they too enjoy the "poor man's music," a phenomenon long-time researcher of the genre, Ferida Jawad, refers to as "the upper class going gangsta for an evening." However, their choice of mahragānāt performers is quite exclusive and includes only the most popular artists, such as Oka and Ortega or El Madfaagiya, who is performing at the Vodaphone IN Tour Cairo this year (YT "IN Tour Cairo"). Even though these few selected artists are more or less embraced by the elite and considered pop stars by now, the public is still generally sceptical towards mahragānāt music and the artists behind it. Thus the gap between well established artists and new young independent artists is very evident [ $\nearrow$ Young vs. Settled].

Apart from mere preference and public opinion, new genres within popular music, such as mahragānāt, seem to be further impacted by politics. The newly appointed committee for "the development of morals and conscience and the promotion of work ethics and values of belonging" plays an important role in this matter (MadaMasr). The Musicians Association now provides a carnet to approved artists and their songs. This grants the artists legal consent to perform in public places, such as hotels, festivals, etc., and their lyrics and songs automatically receive copyrights. These days licensed mahragāna $\bar{t}$ artists include most of the pioneers from the early days of mahragānāt. The "carnet" is, as Ferida Jawad thinks, a double-edged sword, leading to censorship [ $\lambda$ Voice $v$ s. Silence]. In her opinion the system is made with the intention to control the musical scene [ 7 Freedom $v s$. Constraint]:

Because the mahraganat became so popular, the government must have decided it needed to be supervised in a way. Listening to the songs produced by the registered artists over the course of the past year, I have noticed they don't contain as many topics that can be called social criticism anymore (...) There's not a lot left of the spirit of the first songs, which talked about how they were a part of society that was spit out, and how they had had enough of that. (Freemuse)

Despite initiatives to regulate the music scene, there are still voices of protest to be found among Egyptian artists - such as the group Sharmoofers (Shārmūfarz) and their hit Zūmbi (Zombie) that makes fun of the robotic and self-involved people living in ignorance while taking selfies all day long ( $Y T$ "Zūmb $\overrightarrow{1}$ "). The popular song is a warning against a new breed of social media zombies and influencers, indeed a relevant topic these days [ 7 Social Media].

زح่ • 21 (2021) - Themed Section In2016: *206-*213 
Also warning the listener, however in a much more serious tone, is rock band Cairokee's (Kāyrūkī) popular song 'Ākhir 'ughniyya (The last song). Published on their YouTube channel in March, the music video opens with the message "No freedom with fear" (YT "Ākhir 'ughniyya") [ $\nearrow$ Security vs. Fear]. The rest of the song's lyrics are daring as they pinpoint some of the challenges of Egyptian society and the political climate, as well as expressing a wish to break with the old:

They've imprisoned you inside your mind, your fear is the prison bars. You dare not think freely for fear of being caught. My speech is not only against the regime, but is also against slavery. Even if thousands of systems are destroyed (...) a conflict of generations, blindly obvious (...) they want you to walk their path instead of your own. (YT Äkhir 'ughniyya) [ 7 "The System" vs. "The People"]

Many of the new alternative voices of Egypt's music scene are also represented by women. In November, cairoSCENE lists a chosen selection of the best female alternative vocalists of 2016. They make music within a multitude of genres, ranging from folklore, jazz, soul, hiphop, rock, punk, opera and pop music (cairoSCENE [b]). Judging by this myriad, it is not only the music scene itself that is evolving, but also the female aspect of it. Included in the cairoSCENE list is artist and known actress Amina Khalil (Amīna Khalīl). She is recently featured on the big hit Nür (Nour) together with post-revolutionary rapper Zap Tharwat, described by some as the voice of young Egyptians. Nür tells the story of the elder brother of three siblings, a hard worker who becomes the head of the family as his dad suddenly falls ill. With the new responsibility, Nour takes on a job in the father's car shop, while still continuing his studies. He finally graduates, and when the time comes to apply for a job the surprise element in the song is revealed: Nour is not the responsible big brother of a family, but the elder sister of three girls. The music video shows the employer who is obviously shocked to see a female Nour entering with a bright smile. After battling the prejudices racing in his mind, he finally realizes how influenced he is by society's limiting gender perceptions and offers Nour the position after all. The chorus accompanies shots of an unmasked Nour as Amina Khalil sings: "His role will never be completed without her role" (YT "Nūr") [ $\nearrow$ Male $v$ s. Female, 7 Dual Identities / Masking]. The song's theme is significant as it covers several pressing issues: the economic challenges faced by the majority of Egyptians mixed with very high unemployment rates, especially among the younger generation, and finally the social issue regarding gender stereotypes and restrictions on women's role in society.

In Tunisia, artists like 'Medusa' Boutheina El Aloudi (Mīdūzā Buthayna al-'Aluwwadī) are also challenging societal norms, representing women in hip hop with a feminist perspective: a role that according to El Aloudi herself has not always been easy: "[As a female rapper], I was frequently faced with sexual harassment at shows, events [et cetera]. But I don't want to generalize, out of respect for those who don't do it." In the same interview she also explains how there used to be more girls in the Tunisian hip hop scene, but they are now silencing themselves (DJILALI). Most female artists are working abroad these days, and ElAloudi hopes to see new girls following her lead. Luckily, there are still a few, such as Nour Ben Soltan (Nūr Bin Sulțān), a seventeen-year-old B-girl who started her career dancing in community centres and poor neighbourhoods. Since then she has moved on to participate and 
compete in multiple events and festivals in Tunisia, like the Beat the Beat Festival in Sousse where she won in her category (B-girl). Facing the controversy of being a female breakdancer, Ben Soltan's secret lies in her attitude:

How I am perceived by society is my least concern, so long as I can pursue my passion and excel at what I do. It's a question of knowing what you want and at the same time [not succumbing to] the pressure of others. (DJILALI) [ 7 Freedom vs. Constraint]

Whether it is pulsating electronic beats at festive occasions, provoking lyrical content or female hip hoppers challenging gender stereotypes, music and dancing arguably take on an essential role as a means of expression. In the movie Sheikh Jackson, for example, protagonist Khaled (Khālid)'s love for Michael Jackson is what wakes him up and saves him from a state of depression and zombie-like behaviour (Sheikh Jackson). While trying his best to be pious and stay focused on his role as an Islamic cleric, Khaled starts to remember glimpses of his youth [ IIn Islam,...]. Painful memories occur of a troubled upbringing and a strict and violent father, mixed with the longing for his high school crush. The movie depicts how music was his greatest passion and the only means of opposition, however implicit, to his authoritarian father [ $\nearrow$ Father Figures]. Later in life, the news of his pop idol's death triggers repressed feelings, kick-starting an emotional process that makes him able to let go, as he eventually makes peace with his father and his past. In this context music works as an antidote to piety and authority, and thereby serves an important role as a counterpart to the gloomy and grave circumstances Khaled finds himself in. Here, pop music is not seen merely as a shallow form of entertainment 'ignoring' more serious problems, but rather as a sweet and soothing remedy for these very same issues. A parallel can be drawn to musical representation in the movie Clash. In one of the most intense scenes, DJ Mans sits down pressing his phone to his ear with the mahragānāt song Hātì būsa yā bitt ("Give me a kiss, girl") playing, while desperately trying to block out the chaos surrounding him [ $\nearrow$ Mobile Phones]. The music seems to offer DJ Mans some comfort or relief, however small, to the very serious and suffocating situation he is in [ЛHope vs. Hell]. The lively and playful atmosphere of the music is portrayed as a protecting shield against the harsh reality out there.

Pop music's role appears to be multifaceted. One aspect concerns the need for a reality check and a demand for more alternative music tackling social issues, such as gender equality and everyday struggles of poor urban youth. Another one concerns the craving for catchy and dancy music as a remedy during challenging times. Popular songs express both joy and frustration, mirroring different versions of Egyptian reality: Al-Qāhira celebrates Cairo and its beauty while Mafish șăhib yitșāhib addresses the hardship in its slums. Both perspectives are arguably relevant in today's climate. Commenting on Al-Qāhira (whose lyrics he wrote) in the aftermath of the debate it triggered, Tamer Hussein (Tāmir Husayn) says:

The fact that the video was praised by some and criticized by others proves how rich and diverse Cairo is, for it can be seen in a thousand different ways. (FARID) 


\section{Related Entries}

ARRAYs - 'Ashwä iyya $\bar{a} t$ Celebrities Clash Dancing Downtown/Centre-ville Dual Identities / Masking $\downarrow$ In Islam, ... $\gg$ Father Figures $\diamond$ Garbage $\downarrow$ Mobile Phones $\diamond$ Psychiatrists $\diamond$ Social Media Suicide The Voice from Above

CODES - Affluence vs. Destitution $\downarrow$ Beautiful vs. Ugly $\downarrow$ Freedom vs. Constraint $\downarrow$ Hope vs. Hell Male vs. Female Security vs. Fear "The System" vs. "The People" Young vs. Settled

\section{References}

\section{Written Sources and videos}

[cairoSCENE (a) =] N. N. "Amr Diab is Officially a Guinness World Record Winner." cairoSCENE, September 29, 2016, <http://cairoscene.com/Buzz/Amr-Diab-is-Officially-a-Guinness-WorldRecord-Winner>.

[cairoSCENE (b) =] N. N. "17 of Egypt's Best Alternative Female Vocalists." cairoSCENE, November 25, 2016, <http://cairoscene.com/ArtsAndCulture/16-of-Egypt-s-Best-Alternative-FemaleVocalists>.

DJILALI, Emma. "Women in hip hop: Making space for Tunisia's unseen queens." Middle East Eye, August 11, 2016, <https://www.middleeasteye.net/news/women-hip-hop-making-space-tunisiasunseen-queens>.

[@amrdiab] = DIYĀB, 'Amr. Twitter post, posted on September 28, 2016, <https://twitter.com amrdiab?ref_src=twsrc\%5Etfw\%7Ctwcamp \%5Etweetembed\%7Ctwterm\%5E7810979105451212 $80 \&$ ref url=http $\% 3 \mathrm{~A} \% 2 \mathrm{~F} \% 2 \mathrm{Fcairoscene.com} \% 2 \mathrm{FBuzz} \% 2 \mathrm{FAmr}$-Diab-is-Officially-a-GuinnessWorld-Record-Winner>.

FARID, Sonia. "“This is NOT Egypt': Pop song and tourism advert angers many." Al Arabiya, February 15, 2016, <https://english.alarabiya.net/en/2016/02/15/-Thisis-NOT-Egypt-Tourism-campaignand-song-angers-many.html>.

[Freemuse $=]$ N. N. "Egypt: Mahraganat artists challenge limits." Freemuse, February 23, 2016, $<$ https://freemuse.org/news/egypt-mahraganat-artists-challenge-limits/>.

GAMAL, Ali. "The Mahraganat craze with a dark side splitting opinion in Egypt.” BBC Arabic, January 13, 2016, <http://www.bbc.com/news/world-middle-east-35135699>.

[HotArabicMusic]. N. N. "Report: Diva Sherine Abdel-Wahab To Retire And Quit The Mahraganat Biz!" HotArabicMusic, February 29, 2016, <http://hotarabicMusic.com/2016/02/report-divasherine-to-retire-and-quit-the-Music-biz/>.

$[$ MadaMasr $=$ ] N. N. "Sisi approves committee for development of morals and values." MadàMașr November 26, 2015, <https://www.madamasr.com/en/2015/11/26/news/u/sisi-approves-committeefor-development-of-morals-and-values/>.

SAEED, Saeed. "Mawazine 2016: I felt I couldn't go on, says Egyptian singer Sherine Abdel-Wahhab." The National, May 29, 2016, <https://www.thenational.ae/arts-culture/mawazine-2016-i-felt-icouldn-t-go-on-says-egyptian-singer-sherine-abdel-wahhab-1.184652>.

[Vimeo "Kull mghannī" =] N. N. Vimeo video, uploaded 2016, <https://vimeo.com/ 179558547>.

[al-Yawm al-sābi $=]$ N. N. "Mahragān 'Mafĩsh șāhib yitșāhib' yatakhațà al-50 milyūn mushāhada 'alà yūtyūb." al-Yawm al-sābic, March 8, 2016, <https://www.youm7.com/story/2016/3/8/ 261929/

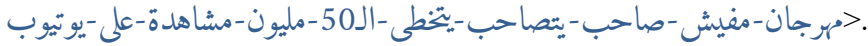

[YT “Ākhir al-Nahār” =] N. N. “Ākhir al-Nahār” episode. YouTube video, uploaded February 10, 2016, $<$ https://www.youtube.com/watch? $\mathrm{v}=\mathrm{xQh0FLe7JSc}>$. 
[YT “"̄khir 'ughniyya” =] N. N. "Ākhir 'ughniyya." YouTube video, uploaded March 12, $<$ https://www.youtube.com/watch? $\mathrm{v}=\mathrm{TZu} 2 \mathrm{euuj} 2 \mathrm{GE}>$.

[YT "Egyptian dancing on the popular song 2016" =] N. N. "Egyptian dancing on the popular song 2016." YouTube video, uploaded April 28, 2016, <https://www.youtube.com/watch?v=jnPDpTQri4>.

[YT "IN Tour Cairo" =] N. N. "IN Tour Cairo." YouTube video, uploaded March 22, 2016, <https:// www.youtube.com/watch?v=8XR63CqM2Nc>.

[YT "Mafĩsh șāḥib yitṣāhib" =] N. N. "Mafîsh șāhịib yitșāḥib." YouTube video, uploaded August 19, 2015, <https://www.Youtube.com/watch?v=pMx5DU2fsp8>.

[YT "Nūr" =] N. N. "Nūr." YouTube video, uploaded November 25, 2016, <https://www.youtube. com/watch? $\mathrm{v}=\mathrm{Z} 3 \mathrm{megGZrFMI}>$.

[YT "Al-Qāhira" =] N. N. "Al-Qāhira". YouTube video, uploaded February 1, 2016, <https://www. youtube.com/watch? $=$ lixPaFt3VV0>.

[YT "This is Egypt" =] N. N. "This is Egypt". YouTube video, uploaded December 10, 2015, $<$ https://www.youtube.com/watch?v=k3KqP69xuPc $>$.

[YT “Zūmbī” =] N. N. “Zūmbī.” YouTube video, uploaded April 1, 2016, <https://www.youtube. com/watch? $=\mathrm{v}=\mathrm{aA0BXDOq7} \mathrm{M}>$.

Movies

Ishtibāk (Clash). By Muhammad Diyāb (Mohamed Diab). Egypt, Germany, France 2016.

Shaykh Jackson (Sheikh Jackson). By `Amr Salāma. Egypt 2017.

\ingvild_tomren@hotmail.com, ingvild.tomren@ikos.uio.no 